\title{
Love and addiction: the devil is in the differences: a commentary on "The behavioral, anatomical and pharmacological parallels between social attachment, love and addiction."
}

\author{
Caroline M. Hostetler • Andrey E. Ryabinin
}

Received: 16 August 2012 /Accepted: 23 August 2012/Published online: 5 September 2012

(C) Springer-Verlag 2012

In their review in the current special issue, Burkett and Young (2012) describe the striking similarities that are observed between attachment and addiction. The idea of love as an addictive drug has been described in art and literature across the ages, as well as by modern scientists (Insel 2003; MacLean 1990). Recent advances have demonstrated that both attachment figures and drugs of abuse are highly rewarding stimuli that lead to long-term changes in physiology and behavior, often utilizing the same neural substrates. The review is thorough and intriguing; however, focusing too narrowly on the similarities between attachment and addiction may hinder our broader understanding of their individual biology as well as their interactions. Indeed, there are significant ways in which addiction and attachment differ, and these merit consideration. Although a full review and discussion of these differences is beyond the scope of this commentary, we provide examples in each neurobiology and behavior.

There is compelling evidence that drugs of abuse and social partners activate and alter common neurotransmitter systems (as reviewed in Burkett and Young 2012). For example, repeated amphetamine and pair bonding each increase dopamine D1 receptors (D1R) in the nucleus accumbens (Aragona et al. 2006; Liu et al. 2010). However, only amphetamine leads to accumulation of $\Delta$ FosB (Hostetler and Bales 2012), a transcription factor found in D1R-containing neurons of the nucleus accumbens that has been strongly implicated in neural plasticity following repeated natural and drug reward (Nestler 2008). This suggests that the changes in D1R following pair bonding are induced via mechanisms that are independent of addiction-related processes.

C. M. Hostetler $(\triangle) \cdot$ A. E. Ryabinin Department of Behavioral Neuroscience,

Oregon Health and Science University,

Portland, Oregon 97239, USA

e-mail: caroline.hostetler@gmail.com
Addiction is partially characterized by a reduction in the rewarding properties of stimuli that are not the drug of abuse (Ahmed and Koob 2005). Similarly, reduced responsiveness to rewarding non-social stimuli has been observed in pairbonded voles and maternal dams (Ferris et al. 2005; Liu et al. 2011; Mattson et al. 2001). In contrast, male titi monkeys that are housed with a pairmate show increased preference and consumption of a rewarding beverage (Ragen et al. 2012). These findings indicate that shifts in reward response following attachment are not universal, and there is a need for more research across an array of species and behaviors.

These examples are quite specific, but fundamental and significant differences are observed on a much broader scale. Addiction is atypical behavior that leads to a severe reduction in the physiological and psychological health and well-being of the individual (NIDA 2012) and exerts a significant cost to society (Mark et al. 2001; Office of National Drug Control Policy 2004; Rehm et al. 2009). While the type of attachment described by Burkett and Young may meet some criteria for addiction (Schaeffer 2009), the vast majority of attachments, including pair bonds, parent-offspring relationships, and friendships, are evolutionarily adaptive behaviors that have been selected upon to promote reproductive fitness, general health, and species-typical behaviors (Carter 1998; Ducharme and Kollar 2012; Gubernick and Teferi 2000; Mcguire et al. 1992; Numan and Insel 2003; Uchino et al. 1996). Given these benefits, it is challenging to see how attachment meets criteria of a DSM-IV disorder.

The similarities and dissimilarities between attachment and addiction may be reconciled using a model that utilizes overlapping, but distinct, neurobiology and behavior (Fig. 1). We agree that neurocircuits involved in actions of drugs of abuse and addiction partially overlap with neural systems involved in social behaviors. This explains the convergence in many, but not all, characteristics of love and addiction. However, striking differences between these 


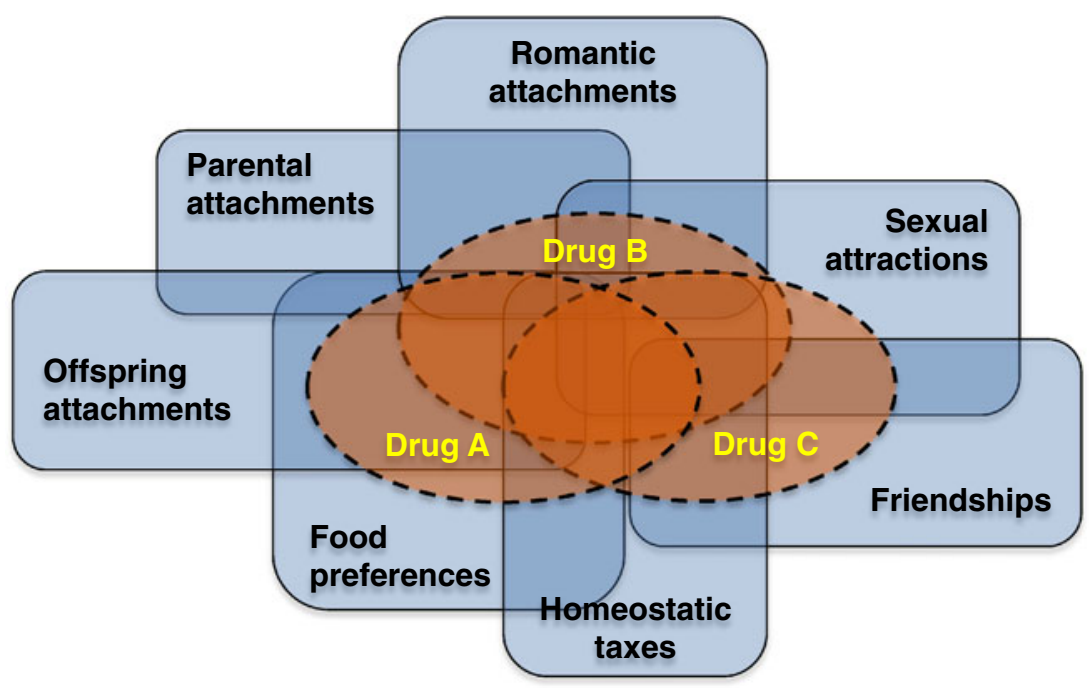

Fig. 1 Neural substrates of social attachment and addiction. Substrates of social attachment behaviors are depicted as partially overlapping squares. Substrates underlying addiction to different drugs (or other addictive behaviors) are depicted as ovals. They are also known to involve partially overlapping mechanisms. While the review by
Burkett and Young focuses on overlaps between these substrates, our commentary stresses that there are many differences. Focusing on the differences could be a more productive approach to treat individuals affected by addiction or mental disorders triggered by social stresses

on drug use and abuse (Anacker et al. 2011a, b; Hostetler and Ryabinin 2012; Liu et al. 2011). In this way, social neuroscience has the potential to provide invaluable and innovative tools for addiction biology. Research on the interaction between the social environment and drug abuse may be particularly informative for prevention and treatments. Rather than the cause of addiction, perhaps love is the drug for treating addiction.

Acknowledgments While writing this commentary, $\mathrm{CMH}$ was supported by NIH 5T32AA007468-24 and AER was supported by NIH RO1 AA019793, U01 AA016647, and P60 AA10760.

\section{References}

Ahmed SH, Koob GF (2005) Transition to drug addiction: a negative reinforcement model based on an allostatic decrease in reward function. Psychopharmacology (Berl) 180:473-490

Anacker AM, Loftis JM, Kaur S, Ryabinin AE (2011a) Prairie voles as a novel model of socially facilitated excessive drinking. Addict Biol 16:92-107

Anacker AM, Loftis JM, Ryabinin AE (2011b) Alcohol intake in prairie voles is influenced by the drinking level of a peer. Alcohol Clin Exp Res 35:1884-1890

Aragona BJ, Liu Y, Yu YJ, Curtis JT, Detwiler JM, Insel TR, Wang ZX (2006) Nucleus accumbens dopamine differentially mediates the formation and maintenance of monogamous pair bonds. Nat Neurosci 9:133-139

Buckner JD, Schmidt NB, Lang AR, Small JW, Schlauch RC, Lewinsohn PM (2008) Specificity of social anxiety disorder as a risk factor for alcohol and cannabis dependence. J Psychiatr Res 42:230-239

Burkett JP, Young LJ (2012) The behavioral, anatomical and pharmacological parallels between social attachment, love and addiction. Psychopharmacology (Berl) 
Carter CS (1998) Neuroendocrine perspectives on social attachment and love. Psychoneuroendocrinology 23:779-818

Charney DA, Zikos E, Gill KJ (2010) Early recovery from alcohol dependence: factors that promote or impede abstinence. J Subst Abuse Treat 38:42-50

Ducharme JK, Kollar MM (2012) Does the "marriage benefit" extend to same-sex union?: evidence from a sample of married lesbian couples in Massachusetts. J Homosex 59:580-591

Ferris CF, Kulkarni P, Sullivan JM Jr, Harder JA, Messenger TL, Febo M (2005) Pup suckling is more rewarding than cocaine: evidence from functional magnetic resonance imaging and threedimensional computational analysis. J Neurosci 25:149-156

Fleckenstein AE, Gibb JW, Hanson GR (2000) Differential effects of stimulants on monoaminergic transporters: pharmacological consequences and implications for neurotoxicity. Eur J Pharmacol 406:1-13

Garmendia ML, Alvarado ME, Montenegro M, Pino P (2008) Social support as a protective factor of recurrence after drug addiction treatment. Rev Med Chil 136:169-178

Gubernick DJ, Teferi T (2000) Adaptive significance of male parental care in a monogamous mammal. Proc Biol Sci 267:147-150

Hajema KJ, Knibbe RA (1998) Changes in social roles as predictors of changes in drinking behaviour. Addiction 93:1717-1727

Heilig M, Egli M (2006) Pharmacological treatment of alcohol dependence: target symptoms and target mechanisms. Pharmacol Ther 111:855-876

Homish GG, Leonard KE (2008) The social network and alcohol use. J Stud Alcohol Drugs 69:906-914

Hostetler CM, Bales KL (2012) DeltaFosB is increased in the nucleus accumbens by amphetamine but not social housing or isolation in the prairie vole. Neuroscience

Hostetler CM, Ryabinin A (2012) Modeling alcohol relapse in the monogamous prairie vole (Microtus ochrogaster). Alcohol Clin Exp Res 36:108A

Hunter-Reel D, McCrady B, Hildebrandt T (2009) Emphasizing interpersonal factors: an extension of the Witkiewitz and Marlatt relapse model. Addiction 104:1281-1290

Insel TR (2003) Is social attachment an addictive disorder? Physiol Behav 79:351-357

Kelly JF, Brown SA, Abrantes A, Kahler CW, Myers M (2008) Social recovery model: an 8-year investigation of adolescent 12-step group involvement following inpatient treatment. Alcohol Clin Exp Res 32:1468-1478

Liu Y, Aragona BJ, Young KA, Dietz DM, Kabbaj M, Mazei-Robison M, Nestler EJ, Wang Z (2010) Nucleus accumbens dopamine mediates amphetamine-induced impairment of social bonding in a monogamous rodent species. Proc Natl Acad Sci U S A 107:1217-1222

Liu Y, Young KA, Curtis JT, Aragona BJ, Wang Z (2011) Social bonding decreases the rewarding properties of amphetamine through a dopamine D1 receptor-mediated mechanism. J Neurosci 31:7960-7966

MacLean PD (1990) The triune brain in evolution. Plenum, New York
Mark TL, Woody GE, Juday T, Kleber HD (2001) The economic costs of heroin addiction in the United States. Drug Alcohol Depend 61:195-206

Mattson BJ, Williams S, Rosenblatt JS, Morrell JI (2001) Comparison of two positive reinforcing stimuli: pups and cocaine throughout the postpartum period. Behav Neurosci 115:683-694

McCrady BS, Zucker RA, Molina BS, Ammon L, Ames GM, Longabaugh R (2006) Social environmental influences on the development and resolution of alcohol problems. Alcohol Clin Exp Res 30:688-699

McGeehan AJ, Olive MF (2003) The mGluR5 antagonist MPEP reduces the conditioned rewarding effects of cocaine but not other drugs of abuse. Synapse 47:240-242

Mcguire B, Russell KD, Mahoney T, Novak M (1992) The effects of mate removal on pregnancy success in prairie voles (Microtus ochrogaster) and meadow voles (Microtus pennsylvanicus). pp $37-42$

McKay JR, Foltz C, Stephens RC, Leahy PJ, Crowley EM, Kissin W (2005) Predictors of alcohol and crack cocaine use outcomes over a 3-year follow-up in treatment seekers. J Subst Abuse Treat 28 (Suppl 1):S73-S82

Nestler EJ (2008) Review. Transcriptional mechanisms of addiction: role of DeltaFosB. Philos Trans R Soc Lond B Biol Sci 363:3245-3255

NIDA (2012) Medical consequences of drug abuse. Available via http://www.drugabuse.gov/related-topics/medical-consequencesdrug-abuse. Accessed 15 Aug 2012.

Numan M, Insel TR (2003) The neurobiology of parental behavior. Springer-Verlag, New York

Office of National Drug Control Policy (2004) The economic costs of drug abuse in the united states, 1992-2002. Executive Office of the President, Washington, DC

Ragen BJ, Mendoza SP, Mason WA, Bales KL (2012) Differences in titi monkey (Callicebus cupreus) social bonds affect arousal, affiliation, and response to reward. Am J Primatol. doi: ajp.22026/ajp.22026

Ramsey AJ, Laakso A, Cyr M, Sotnikova TD, Salahpour A, Medvedev IO, Dykstra LA, Gainetdinov RR, Caron MG (2008) Genetic NMDA receptor deficiency disrupts acute and chronic effects of cocaine but not amphetamine. Neuropsychopharmacology 33:2701-2714

Rehm J, Mathers C, Popova S, Thavorncharoensap M, Teerawattananon Y, Patra J (2009) Global burden of disease and injury and economic cost attributable to alcohol use and alcohol-use disorders. Lancet 373:2223-2233

Schaeffer B (2009) Is it love or is it addiction: the book that changed the way we think about romance and intimacy. Hazelden, Center City, MN

Uchino BN, Cacioppo JT, Kiecolt-Glaser JK (1996) The relationship between social support and physiological processes: a review with emphasis on underlying mechanisms and implications for health. Psychol Bull 119:488-531 